Brit. Heart F., 1967, 29, 906.

\title{
Incidence of Congenital Heart Disease in Nigerian Children
}

\author{
B. GUPTA AND A. U. ANTIA
}

From the Departments of Padiatrics, Adeoyo and University College Hospitals, Ibadan, W. Nigeria

This is an extended study of an investigation of congenital malformations in Nigerian children. Little is known about the incidence and types of congenital heart disease in African children, and there appear to be no detailed reports available either on clinical or necropsy records, except a paper by Caddell and Connor (1966). It is not easy to select a sample of the population that would provide this information. Even in the European series most reports deal with the incidence of congenital heart disease as found at necropsy or at cardiac clinics (Abbott, 1936; Wood, 1950) or in schoolchildren, which obviously excludes cases of severe cardiac malformations dying in infancy (Rauh, 1939; Robinsons, Aggeler, and Daniloff, 1948; Stuckey, 1956). The incidences reported by MacMahon, McKeown, and Record (1953), Carlgren (1959), and Hay (1966) are the most informative.

\section{SUBJECTS AND METHODS}

The present investigation is a survey on the incidence of congenital heart disease in 4220 infants of consecutive births in a large general hospital at Ibadan, Western Nigeria. All children born at Adeoyo hospital between February 1 and July 31, 1964, were included. During the six-month period, 4066 mothers delivered a total of 4220 children. All live births were examined within 24 hours and children in whom congenital heart disease was suspected but not confirmed were followed up. There were 339 deaths (stillbirths 166 and neonatal deaths 173). Necropsy was performed in 327 , including all stillbirths and most neonatal deaths. Detailed case histories of the mothers were not available as most of these mothers came from lower socio-economic groups without any set standard of education.

Received December 28, 1966.

\section{FINDINGS}

Congenital heart disease occurred in 15 children, an incidence of 3.5 per 1000 births. The incidence of all congenital malformations was 3 per cent and malformations of the heart formed one-eighth of the total malformations. There were 29 children among the 4054 live births who had a systolic murmur at birth and who have been kept under observation to decide whether it was significant of a cardiac malformation or not. At 2 years of age, 6 of them still had a loud systolic murmur that certainly indicated a cardiac malformation; 14 had no systolic murmur and no malformation of the heart at the age of 18 months; and of the remaining 9 , the systolic murmur was only faint in 1 of 3 followed for 3 months and in 2 of the 6 followed for six months.

The specific diagnosis of the 6 children who had a constant systolic murmur after 2 years was made by clinical, radiological, and electrocardiographic examinations, without catheterization or angiocardiography. With experience, the diagnosis of congenital heart disease can be reasonably reliable even without these special investigations. Two had patent ductus arteriosus, 2 ventricular septal defect, and 2 pulmonary stenosis (Table I).

Specific diagnosis was made at necropsy in 9 of the 15 affected children. Of the stillbirths, 5 had congenital heart disease-coarctation of aorta (1), patent ductus arteriosus (1), atrial septal defect (1), ventricular septal defect (1), and cor triloculare (1).

Of the neonatal deaths, 4 had congenital heart disease-transposition of the great vessels (2), patent ductus arteriosus (1), and atrial septal defect (1).

In the present series only 4 were found to have congenital malformations of other systems. These 906 
TABLE I

TYPES OF MALFORMATIONS OF THE HEART

\begin{tabular}{|c|c|c|c|c|c|c|c|}
\hline \multirow{2}{*}{ Cardiac malformation } & \multirow{2}{*}{$\begin{array}{l}\text { Living } \\
\text { children }\end{array}$} & \multirow{2}{*}{$\begin{array}{l}\text { Still- } \\
\text { births }\end{array}$} & \multirow{2}{*}{$\begin{array}{l}\text { Neonatal } \\
\text { deaths }\end{array}$} & \multirow{2}{*}{ Total } & \multicolumn{2}{|c|}{ Sex } & \multirow{2}{*}{$\begin{array}{l}\text { Associated } \\
\text { malformations }\end{array}$} \\
\hline & & & & & $\mathbf{M}$ & $\mathrm{F}$ & \\
\hline $\begin{array}{l}\text { Patent ductus arteriosus } \\
\text { Ventricular septal defect } \\
\text { Pulmonary stenosis } \\
\text { Transposition of great vessels } \\
\text { Atrial septal defect } \\
\text { Coarctation of aorta } \\
\text { Cor triloculare }\end{array}$ & $\begin{array}{l}2 \\
2 \\
2 \\
- \\
- \\
- \\
-\end{array}$ & $\begin{array}{l}1 \\
1 \\
\overline{1} \\
1 \\
1\end{array}$ & $\begin{array}{l}\frac{1}{-} \\
\overline{2} \\
1 \\
- \\
-\end{array}$ & $\begin{array}{l}4 \\
3 \\
2 \\
2 \\
2 \\
1 \\
1\end{array}$ & $\begin{array}{l}2 \\
1 \\
2 \\
2 \\
1 \\
1 \\
1\end{array}$ & $\begin{array}{l}2 \\
2 \\
0 \\
0 \\
1 \\
0 \\
0\end{array}$ & $\begin{array}{l}\text { Polydactyly } \\
\text { Bilobed } \\
\text { R. lung } \\
\text { Bilobed } \\
\text { R. lung } \\
\text { Micrognathos }\end{array}$ \\
\hline Total & 6 & 5 & 4 & 15 & 10 & 5 & 4 of 15 \\
\hline
\end{tabular}

TABLE II

MATERNAL AGE AT BIRTH OF 2572 NORMAL AND THE AFFECTED CHILDREN

\begin{tabular}{c|c|c}
\hline $\begin{array}{c}\text { Age } \\
\text { (yr.) }\end{array}$ & $\begin{array}{c}\text { Normal } \\
\text { children }\end{array}$ & $\begin{array}{c}\text { Affected } \\
\text { children }\end{array}$ \\
\hline $15-19$ & 485 & 3 \\
$20-24$ & 913 & 5 \\
$25-29$ & 784 & 5 \\
$30-34$ & 219 & 2 \\
$35-39$ & 152 & 0 \\
$40-44$ & 19 & 0 \\
\hline Total & 2572 & 15 \\
\hline
\end{tabular}

were bilobed right lungs (2), polydactyly (1), and micrognathos (1) (Table I).

Maternal Age. The maternal age at the time of birth of 2572 normal children and 15 affected children during the same period is given in Table II. The accuracy of these cannot be guaranteed in view of the poor histories. No conclusion can be made in regard to influence of maternal age on the incidence of congenital heart disease, though the majority fall between the ages of 15 and 30 years.

Birth Rank. The birth ranks of 3865 normal and 15 affected children were available. Children born to mothers of third parity were most affected in this study (Table III).

Sex Ratios. There were 10 boys and 5 girls in the affected group compared with 2184 boys and 2021 girls in the control series. The sex ratio of boys to girls is $2: 1$, but the numbers are too small to have real statistical value.

\section{Drscussion}

An attempt has been made to record cases of congenital heart disease in 4220 consecutive births of Nigerian children. Diagnosis was confirmed by clinical examination and at necropsy. In compari-
TABLE III

BIRTH RANKS OF AFFECTED AND NORMAL CHILDREN OF 3865 MOTHERS

\begin{tabular}{l|c|c}
\hline \multicolumn{1}{c|}{ Birth ranks } & $\begin{array}{c}\text { No. of normal } \\
\text { children }\end{array}$ & $\begin{array}{c}\text { No. of affected } \\
\text { children }\end{array}$ \\
\hline First parity & 894 & $2(0 \cdot 22 \%)$ \\
Second parity & 933 & $4(0 \cdot 43 \%)$ \\
Third parity & 879 & $5(0.57 \%)$ \\
Fourth parity & 559 & $2(0 \cdot 36 \%)$ \\
Fifth parity & 600 & $2(0 \cdot 33 \%)$ \\
\hline \multicolumn{1}{c|}{ Total } & 3865 & 15 \\
\hline
\end{tabular}

son with the European series the numbers are too small, but since few surveys have been made in children of African origin, the following observations are worth recording.

The incidence of congenital heart disease in this study is 3.5 per 1000 of all births. Holoubek, Holoubek, and Baker (1947) reported 4.8 per cent in 294 deaths in American Negroes; Schwartz, Schamroth, and Seftel (1958) reported $1 \cdot 1$ per cent in a hospital admission of 275 in Africans of Johannesburg; and Tulloch (1958) noted 2.8 per cent in Jamaicans in 1258 necropsies. These figures, of course, do not represent the incidence of congenital heart disease of African origin as they are not drawn from children alone.

MacMahon et al. (1953) concluded that estimates of the incidence at necropsy (reported by Leech, 1935; Potter, 1940, among many others) and in patients admitted to hospital (Roberts, 1937; Thordarson, 1947) vary widely and are equally unsatisfactory as indices of incidence in all births. They found 3.2 per 1000 of live births. Gardiner and Keith (1951) reported $2 \cdot 2$ per 1000 between birth and 15 years. Richards et al. (1955) found it to be 7.6 per 1000 but they included many minor malformations; if these are excluded the figure becomes 2.5 per 1000 . Carlgren (1959) noted 6.4 per 1000 of live births. Recently Campbell (1965) 
confirmed the incidence of heart malformations as 6 per 1000, based on the reports by McKeown and Record (1960) and Carter (1961).

The frequency of the individual lesion is difficult to determine accurately. Most figures depend on whether one considers living or necropsy material, and each author's series in terms of age or type of the disease. The present series is small and no conclusion can be made concerning the incidence of specific malformations. The commonest finding was patent ductus arteriosus (4). MacMahon et al. (1953), Carlgren (1959), Campbell (1965), and Hay (1966) all report that ventricular septal defect is the commonest. This was the second most common in this study.

MacMahon et al. (1953), Lamy, de Grouchy, and Schweisguth (1957), and Campbell (1965) noted that the non-cardiac malformations occurred much more often than would be expected by chance. In this series 4 of the affected children had malformations of other systems and those were not of much significance (Table I).

MacMahon (1952) thought that the third born children were more liable to cardiac malformations, but Campbell (1965) reported that the birth order alone had no influence on the production of malformations of heart. Our figures are not informative as the number involved is small, but they do show that third born children are slightly more often affected and first born children rather less.

In the series of MacMahon (1952) there was some preponderence of affected children in the higher age-groups. In our series the relation of maternal age to malformations is not significant.

There is general agreement that persistent ductus arteriosus is more common in girls than in boys, but that all malformations of the heart taken together are rather more common in boys. Our numbers are very small but are shown in Table I.

The incidence of congenital heart disease in stillbirths is probably higher than all births (MacMahon, 1952), and Jacobius and Moore (1938) recorded a much higher incidence, but Potter (1938) stated that congenital heart disease was not a common cause of stillbirth. There were 3 cases of congenital heart disease per 1000 of stillbirths in this series. Except for the case of cor triloculare and two cases of transposition of the great vessels, cardiac malformations were not the cause of stillbirths.

The history of maternal illness during pregnancy was so poor that no attempt was made to draw any conclusion and the scanty family history of the cases throws no light on the influence of heredity.

\section{SUMMARY}

A survey has been made to find out the incidence of congenital heart disease in a series of consecutive births of 4220 in Nigerian children. The incidence is 3.5 per 1000 , but the figure is provisional as the numbers are small. More detailed study will be required to establish the types of congenital heart disease and the influence of maternal age, parity, illnesses, and genetic factors on congenital heart disease in African children. Our findings are compared with those of the European series.

We are deeply indebted to Professor W. F. Harper, University of Ibadan, for his continued guidance and encouragement in the preparation of this paper. We wish to thank Dr. M. Campbell for his valuable suggestions and criticism of this paper. We are also grateful to the nursing staffs of the maternity department of Adeoyo Hospital, Ibadan, for their co-operation in collecting the data and to Mr. N. O. A. Akinyemi, the Permanent Secretary, Ministry of Health, Western Nigeria for permission to publish.

\section{REFERENCES}

Abbott, M. E. (1936). Atlas of Congenital Cardiac Disease. American Heart Association, New York.

Caddell, J. L., and Connor, D. H. (1966). Congenital heart disease in Ugandan children. Brit. Heart $\mathcal{F}$., 28, 766.

Campbell, M. (1965). Causes of malformations of the heart. Brit. med. F., 2, 895.

Carlgren, L-E. (1959). The incidence of congenital heart disease in children born in Gothenburg 1941-1950. Brit. Heart F., 21, 40.

Carter, C. O. (1961). In Conference on Clinical Aspects of Genetics, 1961, p. 30.

Gardiner, J. H., and Keith, J. D. (1951). Prevalence of heart disease in Toronto children: 1948-1949, cardiac registry. Pediatrics, 7, 713.

Hay, J. D. (1966). Population and clinic studies of congenital heart disease in Liverpool. Brit. med. F., 2, 661.

Holoubek, J. E., Holoubek, A. B., and Baker, DeWitt T. (1947). Heart disease in Charity Hospital of Louisiana in New Orleans. New Orleans med. surg. F., 99, 431.

Jacobius, H. L., and Moore, R. A. (1938). Incidence of congenital cardiac anomalies in the autopsies at the New York Hospital. F. techn. Meth., 18, 133.

Lamy, M., de Grouchy, J., and Schweisguth, O. (1957). Genetic and non-genetic factors in the etiology of congenital heart disease; a study of 1188 cases. Amer. $\mathcal{F}$. hum. Genet., 9, 17.

Leech, C. B. (1935). Congenital heart disease: clinical analysis of 75 cases from the Johns Hopkins. $\mathcal{F}$. Pediat., 7, 802.

McKeown, T. A., and Record, R. G. (1960). In Ciba Foundation Symposium on Congenital Malformations, ed. G. E. W. Wolstenholme and C. M. O'Connor, p. 5. Churchill, London.

MacMahon, B. (1952). Association of congenital malformation of the heart with birth rank and maternal age. Brit. F. soc. Med., 6, 178.

$\longrightarrow$, McKeown, T., and Record, R. G. (1953). The incidence and life expectation of children with congenital heart disease. Brit. Heart F., 15, 121.

Potter, E. L. (1938). Postmortem examination of stillborn and of newly born infants. Arch. Path., 25, 607.

- (1940). Fetal and neonatal deaths: a statistical analysis of 2000 autopsies. F. Amer. med. Ass., 115, 996. 
Rauh, L. W. (1939). The incidence of organic heart disease in the school children of Cincinnati. F. Med., 20, 30.

Richards, M. R., Merritt, K. K., Samuels, M. H., and Langman, A. G. (1955). Congenital malformations of the cardiovascular system in a series of 6053 infants. Pediatrics, 15, 12.

Roberts, J. T. (1937). The incidence of congenital heart disease in the New Orleans Charity Hospital. f. techn. Meth., 17, 108.

Robinsons, S. J., Aggeler, D. M., and Daniloff, G. T. (1948). Heart disease in San Francisco school children: 1947 registry showing incidence, problems, and supervision techniques. F. Pediat., 33, 49.
Schwartz, M. B., Schamroth, L., and Seftel, H. C. (1958). The pattern of heart disease in the urbanized (Johannesburg) African. Med. Proc., 4, 275.

Stuckey, D. (1956). Congenital heart defects following maternal rubella during pregnancy. Brit. Heart f., 18, 519.

Thordarson, O. (1947). Clinical studies on the relative incidence of congenital heart disease. Acta med. scand., 127, 233.

Tulloch, J. A. (1958). Heart disease in Jamaica. W. Indian med. F., 7, 169.

Wood, P. (1950). Congenital heart disease: a review of its clinical aspects in the light of experience gained by means of modern techniques. Brit. med. f., 2, 639. 